\title{
Presence of Listeria species in ready-made meatballs offered by sale under freezing or cooling preservation
}

\author{
Özgür İŞLEYİCia ${ }^{\star}$, Yakup Can SANCAK ${ }^{\mathrm{b}}$, Rabia Mehtap TUNCAY ${ }^{\mathrm{c}}$, Mustafa ATLAN ${ }^{\mathrm{d}}$ \\ Van Yuzuncu Y1l University, Faculty of Veterinary Medicine, Department of Food Hygiene and Technology, Van, Turkey. \\ ${ }^{\mathrm{a} O R C I D:}$ 0000-0001-6319-3880; ' $\mathrm{ORCID:}$ 0000-0003-4490-9606; ' $\mathrm{CRCID}$ : 0000-0002-3510-5369; \\ ${ }^{\mathrm{d} O R C I D:}$ 0000-0003-1444-7316

${ }^{凶}$ Corresponding author: oisleyici @ yyu.edu.tr
Received date: $26.10 .2018-$ Accepted date: 26.04 .2019

\begin{abstract}
This study was conducted to detect contamination level of Listeria species in ready-made meatballs kinds that are stored under frozen or cooled conditions. In isolations and identifications of Listeria species from the samples, method approved and suggested by USDA/FSIS (United States Department of Agriculture/Food Safety and Inspection Service) was used. The strains that were identified to be Listeria monocytogenes with biochemical tests was verified as species through Real Time PCR method by using a primary pair specific to hly $A$ gene location. In this study, a total number of 290 different type ready-made meatball samples were analysed. As a result of examining all samples was isolated L. monocytogenes in 32 (11.04\%) samples, L. ivanovii in $9(3.10 \%)$ samples, L. innocua in $22(7.59 \%)$ samples, L. welchimerii in $8(2.76 \%)$ samples and also L. seeligeri in $4(1.38 \%)$ samples. In the serotyping of the 32 L. monocytogenes strains isolated from the samples; 15 isolated are found to be Type 1, where 3 strains are found to be Type 4, 11 strains to be type Poly and the rest 3 strains could not typified. The Mean $\mathrm{pH}$ and water activity values for the samples were found to be $6.62 \pm 0.56$ and $0.985 \pm 0.007$ respectively. In the result of the study, identifying Listeria species especially L. monocytogenes in cooled and frozen ready-made meatball samples studied suggest that such products whose consumption increased in the recent years pose important risk in terms of public health.
\end{abstract}

Keywords: Listeria monocytogenes, Listeria species, meatball, PCR.

\section{Dondurma veya soğutma ile muhafaza edilerek satışa sunulan hazır köftelerde Listeria türlerinin varlığı}

Özet: Bu çalışma, kasap, şarküteri ve süpermarketlerde dondurulmuş veya soğutulmuş olarak muhafaza edilen ve satışa sunulan hazır köfte çeşitlerinde Listeria türlerinin kontaminasyon düzeyini ortaya koymak amacıyla yapılmıştır. Örneklerden Listeria türlerinin izolasyon ve identifikasyonunda USDA/FSIS (United States Department of Agriculture/Food Safety and Inspection Service) tarafindan önerilen yöntem kullanılmıştır. Biyokimyasal testlerle L. monocytogenes olarak identifiye edilen suşların hly A gen bölgesine spesifik bir primer çifti kullanılarak Real Time PCR yöntemiyle tür olarak doğrulaması yapılmıştır. Çalışmada toplam 290 adet hazır köfte örneği analize alınmıştır. Tüm örneklerin 32 (\%11.04) tanesinden L. monocytogenes, 9 (\%3.10) tanesinden L. ivanovii, 22 (\%7.59) tanesinden L. innocua, 8 (\%2.76) tanesinden L. welchimeri ve 4 (\%1.38) tanesinden de L. seeligeri izole edilmiştir. Yapılan serotiplendirmede izole edilen 32 adet $L$. monocytogenes türünden 15 tanesi Tip 1, 3 tanesi Tip 4 ve 11 tanesi de Tip Poli olarak tanımlanmış, 3 izolat ise tiplendirilememiştir. Tüm örneklerde ortalama $\mathrm{pH}$ değeri $6.62 \pm 0.56$ olarak bulunurken, su aktivitesi değeri ise ortalama $0.985 \pm 0.007$ olarak saptanmıştır. Çalışma sonucunda incelenen örneklerde önemli oranlarda Listeria türlerinin, özellikle de L. monocytogenes'in tespit edilmesi, son y1llarda tüketimi gittikçe artan bu ürünlerin halk sağllğı açısından önemli bir risk oluşturabileceğini göstermektedir.

Anahtar sözcükler: Köfte, Listeria monocytogenes, Listeria türleri, PCR.

\section{Introduction}

Ready-made meatballs produced from red meat and poultry meat have become an ever increasing significant group of food in the recent years in parallel to the developments made in ready-made and semi-ready food industry. If these meatballs where various production techniques and different ingredients are used in production process are not going to be consumed immediately, they should be subjected to cold chain or commonly stored under frozen conditions $(1,19,26)$.

Ready-made meatballs are often contaminated with microorganisms due to hygiene-related mistakes made during their production. Even if the meatballs are preserved by cooling or freezing once they are produced, 
these pathogens, especially the ones with psychrophilic properties, are able to sustain their lives. If the cold chain is broken before the time the product is consumed, it may lead to a rapid multiplication of such pathogens, causing significant risks for the public health $(8,18,19)$. Preservation by cooling and freezing are effective methods to limit the reproduction of pathogenic and nonpathogenic microorganisms in food. That being said, some psychrophilic microorganisms like L. monocytogenes are still able to multiply in cold-stored food and may cause infections $(16,19)$.

Various sources like additives, tools, equipment, personnel, water, environment, cross-contamination, and refrigerators may play a role in contamination of readymade meatballs with Listeria species (11, 12,18). Many studies in the past have revealed the fact that refrigerated or frozen ready-made meatballs offered to market are contaminated with substantial amounts of pathogenic and non-pathogenic microorganisms $(8,19,24,28,29)$. This study aims to reveal the presence and prevalence of Listeria species especially that of L. monocytogenes in the refrigerated or frozen ready-made meatballs put up for sale in butchers, charcuteries and supermarkets in Van city (Turkey).

\section{Materials and Methods}

In this study, a total number of 290 ready-made meatball samples were analysed namely as follows; 50 pieces of Inegol kofte, 40 pieces of hamburger kofte; and 20 pieces each of; Tekirdag kofte, Akcaabat kofte, Adana kofte, Tire kofte, Izmir kofte, kasap kofte, crzbız kofte, odun kofte, satır kofte, and izgara kofte (Kofte is a word in Turkish language and it is the counterpart of meatball in English language. Sample names were kept in their original marketed names). The samples were selected and collected by using simple randomly sampling method from the refrigerated or frozen ready-made meatballs offered by sale in butchers, charcuteries and supermarkets in Van city (Turkey) during January 2015-August 2015. All samples taken for analysis were consisted of the products of companies producing and selling throughout the country. The samples were collected 200 grams minimum in weight (about 10 samples each week), and they were transported to the laboratory within 2 hours max after collection in cold chain $\left(+4{ }^{\circ} \mathrm{C}\right)$, either in their original packaging or in aseptic sterile jars. Production dates, expiry dates and product batch numbers of samples of the same brand or same type were checked to ensure that they did not belong to the same production group.

Physicochemical analyses: The $\mathrm{pH}$ values of the samples were measured using calibrated $\mathrm{pH}$-meters (Hanna ${ }^{\circledR}$ PH 221, Hanna Instruments, Italy), while their water activity was measured using a calibrated $\mathrm{a}_{\mathrm{w}}$ device (Novasina ${ }^{\circledR}$ MS 1 Set, Switzerland).
Isolation and identification of Listeria species: For this purpose, pre-enrichment of the samples was conducted in Listeria Primary Selective Enrichment Broth (Oxoid CM863+SR142) where their selective enrichment was conducted in Listeria Secondary Selective Enrichment Broth (Oxoid CM863+SR143). From both of the enrichment broths, inoculation by a colony each is made by streaking method from Listeria Selective Agar (LSA) (Oxoid CM856+SR140). Typical colonies in 1-3 $\mathrm{mm}$ diameter with grey-brown colour surrounded by black colour are evaluated as Listeria-suspicious $(9,15)$.

The colonies growing in the LSA were purified on the Tryptone Soy Agar (containing 0.6\% Yeast Extract) and identification of purified colonies were made by subjected to Henry's Oblique Illumination Test and other conventional tests of identification (Gram staining, catalase, oxidase, urea, motility, methyl red/VogesProskauer, $\beta$-hemolysis, CAMP, nitrate and glucose, sorbitol, D-mannitol, L-rhamnose, D-xylose fermentation) $(14,20,22)$.

Confirmation of identified $L$. monocytogenes species with PCR: In order to confirm L. monocytogenes species with PCR, the modified method developed by Aznar and Alarcón's (6) from Border et al. (7) was used. In this purpose, in order to detect hly $A$ gene in the samples, specific primary pair to this zone (LMF: CCTAAGACGCCAATCGAA; LMR: AAGCGCTTG CAACTGCTC) and instant commercial master mix $\left(\right.$ GeneAll $^{\circledR}$, Real. Amp ${ }^{\mathrm{TM}}$ SYBR qPCR Master Mix, Korea) was used. From the colonies identified as $L$. monocytogenes, DNA extraction was made by using commercial kits $\left(\right.$ GeneAll ${ }^{\circledR}$, Exgene ${ }^{\mathrm{TM}}$ Cell SV). PCR tubes prepared separately for each Listeria-suspicious DNA extract are placed in real-time PCR device (Rotor GeneTM 6000 Corbett Research, Australia) and upon denaturation phase for $30 \mathrm{sec}$ in $94{ }^{\circ} \mathrm{C}, 45 \mathrm{sec}$ of bonding in $55.5^{\circ} \mathrm{C}, 45 \mathrm{sec}$ of extension in $72^{\circ} \mathrm{C}$ and $5 \mathrm{~min}$ of final extension in $72{ }^{\circ} \mathrm{C}$ phases, totally 35 cycle of PCR amplification is applied. In the results of the application, locations of positive controls and negative control samples in graph were investigated.

Serological tests: In order to determine the serotypes of $L$. monocytogenes strains, was made aglutination test with commercial antiseras (BD Difco Listeria O Antisera Type 1, 4 and Poly) (4).

Reference strains: The L. monocytogenes, Staphylococcus aureus, and Rhodococcus equii strains used in the research were obtained from Etlik Central Veterinary Control \& Research Institute (Ankara, Turkey).

Statistical analysis: In this study, samples were selected and collected by using simple randomly sampling method. As the mean $\mathrm{pH}$ values determined in 12 different ready-made meatballs varieties showed normal 
distribution in Kolmogorov-Smirnov test, one-way analysis of variance was applied for detection of statistically relation of between mean $\mathrm{pH}$ values of different kofte groups. The Duncan multiple comparison test was used to determine the significant differences as a result of the variance analysis. Since the $a_{w}$ values determined in 12 different meatball groups did not show normal distribution as a result of Kolmogorov-Smirnov test, Kruskal-Wallis and Mann-Whitney tests were applied. Pearson correlation analysis was used to determine the relationship between $\mathrm{pH}$ and water activity $\left(a_{w}\right)$ in each type of meatballs. The statistical analysis was performed using SPSS 23 statistical software program (2).

\section{Results}

Listeria species isolated from ready-made meatball samples and PCR verification with serotype distribution of L. monocytogenes isolated are given in Table 1 and Figure 1. Taking all the samples into consideration, $L$. monocytogenes is found to have the highest isolation rate $(11.04 \%)$ and it is followed by L. innocua $(7.59 \%), L$. ivanovii $(3.10 \%)$, L. welchimeri $(2.76 \%)$ and L. seeligeri $(1.38 \%)$ respectively. Table 2 , Table 3 and Table 4 represents the levels of statistical significances of the ready-made meatball sample groups' and sub-groups' $\mathrm{pH}$ and water activity differences.

Table 1. The distribution of Listeria species in the samples and the serotyping of L. monocytogenes isolates.

Tablo 1. Örneklerde belirlenen Listeria türlerinin dağılımı ve L. monocytogenes' in serotiplendirilmesi.

\begin{tabular}{|c|c|c|c|c|c|c|c|c|c|c|c|c|}
\hline \multirow[b]{2}{*}{ Sample type } & \multirow[b]{2}{*}{ Meat species } & \multirow[b]{2}{*}{$\mathbf{n}$} & \multicolumn{6}{|c|}{ Numbers of positive samples } & \multicolumn{4}{|c|}{ Serotypes of $L$. monocytogenes } \\
\hline & & & $\begin{array}{l}\text { Listeria spp. } \\
\text { positive } \\
\text { samples }\end{array}$ & $\underset{\text { monocytogenes }}{L .}$ & $\underset{\text { ivanovii }}{L .}$ & $\stackrel{L}{L}$ & $\begin{array}{c}L . \\
\text { welchimeri }\end{array}$ & $\underset{\text { seeligeri }}{L .}$ & Tip 1 & Tip 4 & $\begin{array}{l}\text { Tip } \\
\text { poli }\end{array}$ & $\begin{array}{l}\text { Not } \\
\text { typed }\end{array}$ \\
\hline \multirow{6}{*}{ Inegol kofte } & Chicken (F) & 10 & $3(30 \%)$ & $2(20 \%)$ & ND & $\mathbf{1}(10 \%)$ & $\mathbf{1}(10 \%)$ & ND & $1(10 \%)$ & - & $1(10 \%)$ & - \\
\hline & Turkey (F) & 10 & $3(30 \%)$ & $1(10 \%)$ & $1(10 \%)$ & ND & $1(10 \%)$ & ND & $1(10 \%)$ & - & - & - \\
\hline & Beef $(C)$ & 10 & $3(30 \%)$ & ND & $1(10 \%)$ & $2(20 \%)$ & ND & ND & - & - & - & - \\
\hline & Beef $(F)$ & 10 & $0(0 \%)$ & ND & ND & ND & ND & ND & - & - & - & - \\
\hline & Beef+Lamb (F) & 10 & $2(20 \%)$ & $1(10 \%)$ & ND & $1(10 \%)$ & ND & ND & - & - & $1(10 \%)$ & - \\
\hline & Total samples & 50 & $11(22 \%)$ & $4(8 \%)$ & $2(4 \%)$ & $4(8 \%)$ & $2(4 \%)$ & $0(0 \%)$ & $2(4 \%)$ & $0(0 \%)$ & $1(2 \%)$ & $0(0 \%)$ \\
\hline $\begin{array}{l}\text { Tekirdag } \\
\text { kofte }\end{array}$ & Beef $(F)$ & 20 & $5(25 \%)$ & $3(15 \%)$ & $1(5 \%)$ & $2(10 \%)$ & ND & ND & $1(5 \%)$ & - & $1(5 \%)$ & $1(5 \%)$ \\
\hline $\begin{array}{l}\text { Akcaabat } \\
\text { kofte }\end{array}$ & Beef $(F)$ & 20 & $4(20 \%)$ & $2(10 \%)$ & $1(5 \%)$ & $1(5 \%)$ & ND & ND & $2(10 \%)$ & - & - & - \\
\hline Adana kofte & Beef $(F)$ & 20 & $3(15 \%)$ & $1(5 \%)$ & $\mathrm{ND}$ & $\mathrm{ND}$ & $2(10 \%)$ & ND & - & - & $1(5 \%)$ & - \\
\hline Tire kofte & Beef (F) & 20 & $7(35 \%)$ & $3(15 \%)$ & $2(10 \%)$ & $2(10 \%)$ & $1(5 \%)$ & ND & $2(10 \%)$ & $1(5 \%)$ & - & - \\
\hline Izmir kofte & Beef (F) & 20 & $6(30 \%)$ & $3(15 \%)$ & $2(10 \%)$ & ND & ND & $1(5 \%)$ & $1(5 \%)$ & - & $2(10 \%)$ & - \\
\hline \multirow{5}{*}{$\begin{array}{l}\text { Hamburger } \\
\text { kofte }\end{array}$} & Beef (F) & 10 & $1(10 \%)$ & $1(10 \%)$ & $\mathrm{ND}$ & ND & $\mathrm{ND}$ & ND & $1(10 \%)$ & - & - & - \\
\hline & Beef (C) & 10 & $2(20 \%)$ & $1(10 \%)$ & $\mathrm{ND}$ & $1(10 \%)$ & ND & ND & $1(10 \%)$ & - & - & - \\
\hline & Chicken $(\mathrm{F})$ & 10 & $1(10 \%)$ & ND & ND & $1(10 \%)$ & ND & $\mathbf{1}(10 \%)$ & - & - & - & - \\
\hline & Chicken (C) & 10 & $3(30 \%)$ & $2(20 \%)$ & $\mathrm{ND}$ & $1(10 \%)$ & ND & ND & - & $1(10 \%)$ & - & $1(10 \%)$ \\
\hline & Total samples & 40 & $7(17.5 \%)$ & $4(10 \%)$ & $0(0 \%)$ & $3(7.5 \%)$ & $0(0 \%)$ & $1(2.5 \%)$ & $2(5 \%)$ & $1(2.5 \%)$ & $0(0 \%)$ & $1(2.5 \%)$ \\
\hline \multirow{3}{*}{$\begin{array}{l}\text { Butcher } \\
\text { kofte }\end{array}$} & Beef (F) & 10 & $2(20 \%)$ & $1(10 \%)$ & $1(10 \%)$ & ND & ND & ND & $1(10 \%)$ & - & - & \\
\hline & Beef $(C)$ & 10 & $3(30 \%)$ & $\mathbf{1}(10 \%)$ & ND & $3(30 \%)$ & ND & ND & - & - & $1(10 \%)$ & \\
\hline & Total samples & 20 & $5(25 \%)$ & $2(10 \%)$ & $1(5 \%)$ & $3(15 \%)$ & $0(0 \%)$ & $0(0 \%)$ & $0(0 \%)$ & $0(0 \%)$ & $1(5 \%)$ & $0(0 \%)$ \\
\hline \multirow{3}{*}{ Cizbız kofte } & Beef+Lamb (C) & 10 & $3(30 \%)$ & $1(10 \%)$ & ND & $2(20 \%)$ & ND & ND & - & - & $1(10 \%)$ & - \\
\hline & Beef $(F)$ & 10 & $4(40 \%)$ & $1(10 \%)$ & $\mathrm{ND}$ & $2(20 \%)$ & $1(10 \%)$ & ND & $1(10 \%)$ & - & - & - \\
\hline & Total samples & 20 & $7(35 \%)$ & $2(10 \%)$ & $0(0 \%)$ & $4(20 \%)$ & $1(5 \%)$ & $0(0 \%)$ & $1(5 \%)$ & $0(0 \%)$ & $1(5 \%)$ & $0(0 \%)$ \\
\hline Odun kofte & Beef $(F)$ & 20 & $5(25 \%)$ & $4(20 \%)$ & ND & ND & ND & $1(5 \%)$ & $1(5 \%)$ & $1(5 \%)$ & $1(5 \%)$ & $1(5 \%)$ \\
\hline Satır kofte & Beef (F) & 20 & $2(10 \%)$ & $2(10 \%)$ & $\mathrm{ND}$ & ND & $2(10 \%)$ & ND & - & - & $2(10 \%)$ & - \\
\hline Izgara kofte & Beef $(F)$ & 20 & $5(25 \%)$ & $2(10 \%)$ & ND & $3(15 \%)$ & ND & $1(5 \%)$ & $2(10 \%)$ & - & - & - \\
\hline & samples & 290 & $\begin{array}{c}97 \\
(33.45 \%)\end{array}$ & $\begin{array}{c}32 \\
(11.04 \%)\end{array}$ & $\begin{array}{c}9 \\
(3.10 \%)\end{array}$ & $\begin{array}{c}22 \\
(7.59 \%)\end{array}$ & $\begin{array}{c}8 \\
(2.76 \%)\end{array}$ & $\begin{array}{c}4 \\
(1.38 \%)\end{array}$ & $\begin{array}{c}15 \\
(5.17 \%)\end{array}$ & $\begin{array}{c}3 \\
(1.04 \%)\end{array}$ & $\begin{array}{c}11 \\
(3.79 \%)\end{array}$ & $\begin{array}{c}3 \\
(1.04 \%)\end{array}$ \\
\hline
\end{tabular}

F: Frozen, C: Cooled, ND: Not Detected, The bold numbers in the same column indicate that two different species were isolated from a single sample 


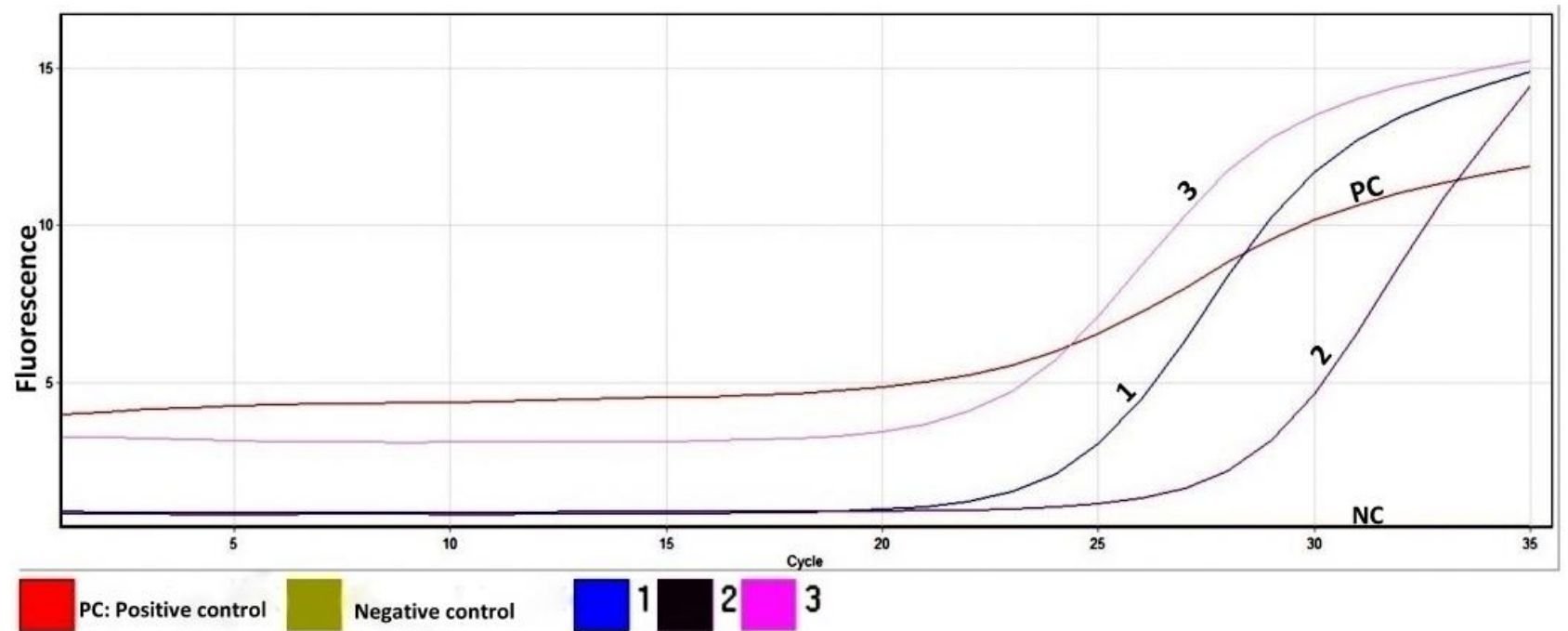

Figure 1. The graphics of PCR amplification of DNA extracts obtained from positive control, negative control, and some $L$. monocytogenes strains isolated from samples.

Şekil 1. Örneklerden izole edilen bazı L. monocytogenes suşları ile pozitif ve negative kontrolden elde edilen DNA ekstraktlarının PCR amplifikasyon grafikleri.

Table 2. The mean $\mathrm{pH}$ values of sample groups and the statistical significance of the differences in the between of mean $\mathrm{pH}$ value of the different types samples within the same sample groups and between the different sample groups.

Tablo 2. Örnek gruplarında belirlenen ortalama pH değerleri ve farklı örnek grupları arasındaki ve örnek grupları içindeki farklı tip hazır köfte örneklerinin ortalama $\mathrm{pH}$ değeri farklılıklarının istatistiksel önem dereceleri

\begin{tabular}{lccc}
\hline \multirow{2}{*}{ Sample name } & Meat and preservation type & $\mathbf{n}$ & pH \\
\cline { 2 - 3 } & Chicken/Freezing & 10 & Mean \pm SE \\
Inegol kofte & Turkey/Freezing & 10 & $7.761 \pm 0.047^{\mathrm{C}}$ \\
& Beef/Cooling & 10 & $6.564 \pm 0.120^{\mathrm{xC}}$ \\
Tekirdag kofte & Beef/Freezing & 10 & $7.426 \pm 0.052^{\mathrm{aA}}$ \\
Akcaabat kofte & Beef +Lamb/Freezing & 10 & $7.118 \pm 0.089^{\mathrm{B}}$ \\
Adana kofte & Beef/Freezing & 20 & $7.123 \pm 0.079^{\mathrm{b}}$ \\
Tire kofte & Beef/Freezing & 20 & $6.077 \pm 0.046^{\mathrm{e}}$ \\
Izmir kofte & Beef/Freezing & 20 & $6.471 \pm 0.072^{\mathrm{d}}$ \\
& Beef/Freezing & 20 & $6.723 \pm 0.061^{\mathrm{c}}$ \\
Hamburger kofte & Beef/Freezing & 20 & $7.094 \pm 0.052^{\mathrm{b}}$ \\
& Beef/Freezing & 10 & $6.013 \pm 0.117^{\mathrm{efA}}$ \\
Kasap kofte & Beef/Cooling & 10 & $6.206 \pm 0.071^{\mathrm{yA}}$ \\
& Chicken/Freezing & 10 & $6.241 \pm 0.087^{\mathrm{A}}$ \\
Cizbiz kofte & Chicken/Cooling & 10 & $6.213 \pm 0.099^{\mathrm{A}}$ \\
Odun kofte & Beef/Freezing & 10 & $6.343 \pm 0.128^{\mathrm{dA}}$ \\
Satır kofte & Beef/Cooling & 10 & $6.366 \pm 0.099^{\mathrm{yA}}$ \\
\hline
\end{tabular}

The difference between the means marked with different small letters in the same column are statistically significant $(\mathrm{P}<0.05)$ (for the groups of frozen beef meatball). The difference between the means marked with different capital letters in the same column are statistically significant $(\mathrm{P}<0.05)($ for different types of samples within Inegol kofte, hamburger kofte, kasap kofte and cızbiz kofte groups).

The difference between the means marked with different $\mathrm{x}, \mathrm{y}, \mathrm{z}$ letters in the same column are statistically significant $(\mathrm{P}<0.05)$ (for the groups of cooled beef meatball). 
Table 3. The statistical significance of the differences in the mean rank aw values of ready-made beef meatballs groups offered by sale under cooling or freezing preservation.

Tablo 3. Soğukta veya dondurarak muhafaza altında satışa sunulan hazır sığır eti kofte örneği gruplarının ortalama rank aw değerlerinin farklarının istatistiksel önem dereceleri.

\begin{tabular}{|c|c|c|c|}
\hline \multirow{2}{*}{ Sample name } & \multirow{2}{*}{ Meat and preservation type } & \multirow{2}{*}{$\mathbf{n}$} & aw \\
\hline & & & Mean rank \\
\hline \multirow{2}{*}{ Inegol kofte } & Beef/Cooling & 10 & $16.450^{x y}$ \\
\hline & Beef/Freezing & 10 & $38.350^{\mathrm{e}}$ \\
\hline Tekirdag kofte & Beef/Freezing & 20 & $63.300^{\text {ed }}$ \\
\hline Akcaabat kofte & Beef/Freezing & 20 & $46.800^{\mathrm{ed}}$ \\
\hline Adana kofte & Beef/Freezing & 20 & $75.280^{\mathrm{cd}}$ \\
\hline Tire kofte & Beef/Freezing & 20 & $119.850^{c}$ \\
\hline Izmir kofte & Beef/Freezing & 20 & $80.880^{\mathrm{bc}}$ \\
\hline \multirow{2}{*}{ Hamburger kofte } & Beef/Freezing & 10 & $153.550^{\mathrm{ab}}$ \\
\hline & Beef/Cooling & 10 & $10.050^{y}$ \\
\hline \multirow{2}{*}{ Kasap kofte } & Beef/Freezing & 10 & $145.550^{\mathrm{ab}}$ \\
\hline & Beef/Cooling & 10 & $20.000^{x}$ \\
\hline Cizbız kofte & Beef/Freezing & 10 & $63.950^{\mathrm{ab}}$ \\
\hline Odun kofte & Beef/Freezing & 20 & $110.130^{\mathrm{bc}}$ \\
\hline Satır kofte & Beef/Freezing & 20 & $164.030^{\mathrm{a}}$ \\
\hline Izgara kofte & Beef/Freezing & 20 & $144.050^{\mathrm{ab}}$ \\
\hline
\end{tabular}

The difference between the mean ranks marked with different small letters in the same column are statistically significant $(\mathrm{P}<0.05)$ (for the groups of frozen beef meatball). The difference between the mean ranks marked with different $\mathrm{x}, \mathrm{y}, \mathrm{z}$ letters in the same column are statistically significant $(\mathrm{P}<0.05)$ (for the groups of cooled beef meatball).

Table 4. The statistical significance of the differences of mean rank $a_{w}$ values within the group in the ready-made meatball sample groups offered for sale under cooling or freezing preservation.

Tablo 4. Soğukta veya dondurarak muhafaza altında satışa sunulan hazır kofte örneği gruplarında, grup içi ortalama rank $a_{w}$ değerlerinin farklarının istatistiksel önem dereceleri

\begin{tabular}{|c|c|c|c|}
\hline \multirow{2}{*}{ Sample name } & \multirow{2}{*}{ Meat and preservation type } & \multirow{2}{*}{$\mathbf{n}$} & \multirow{2}{*}{$\frac{\mathbf{a}_{w}}{\text { Mean rank }}$} \\
\hline & & & \\
\hline \multirow{5}{*}{ Inegol kofte } & Chicken/Freezing & 10 & $20.450^{c}$ \\
\hline & Turkey/Freezing & 10 & $38.400^{\mathrm{a}}$ \\
\hline & Beef/Cooling & 10 & $29.250^{\mathrm{b}}$ \\
\hline & Beef/Freezing & 10 & $11.500^{\mathrm{d}}$ \\
\hline & Beef + Lamb/Freezing & 10 & $27.900^{\mathrm{b}}$ \\
\hline \multirow{4}{*}{ Hamburger kofte } & Beef/Freezing & 10 & $32.400^{\mathrm{a}}$ \\
\hline & Beef/Cooling & 10 & $21.000^{\mathrm{b}}$ \\
\hline & Chicken/Freezing & 10 & $16.650^{\mathrm{bc}}$ \\
\hline & Chicken/Cooling & 10 & $11.950^{\mathrm{c}}$ \\
\hline \multirow{2}{*}{ Kasap kofte } & Beef/Freezing & 10 & $12.220^{\mathrm{a}}$ \\
\hline & Beef/Cooling & 10 & $8.800^{\mathrm{a}}$ \\
\hline \multirow{2}{*}{ Cizbız kofte } & Beef + Lamb/Cooling & 10 & $8.400^{\mathrm{a}}$ \\
\hline & Beef/Freezing & 10 & $12.400^{\mathrm{a}}$ \\
\hline
\end{tabular}

The difference between the mean ranks marked with different small letters in the same column are statistically significant $(\mathrm{P}<0.05)$.

\section{Discussion and Conclusion}

Meatballs represent an important group of readymade foods. They are produced using minced meat, oil, various spices and filling materials, and are offered for sale either in raw form or after undergoing thermal semiprocessing in oil. Listeria species, and especially the pathogenic species of $L$. monocytogenes, are readily encountered in meatballs, and cooling or freezing process doesn't affect their presence in foods drastically $(16,18$, 19, 21, 27).

Many studies conducted in Turkey have displayed that hygienic quality in ready-made meatballs and other 
similar products show variability and that these products can be contaminated with various pathogenic microorganisms $(18,24,29)$.

Of the 290 meatball samples in this study, Listeria spp. was isolated from $97(33.45 \%)$ of them, while $L$. monocytogenes was isolated from $32(11.04 \%)$ of those (Table 1). These results are concordant to other studies in the literature which report very low hygienic quality for meatballs $(8,18,24,29)$.

When the results are inspected, it can be seen that Listeria spp. was isolated from all the samples, except for the Inegol kofte made from beef which were preserved by freezing. It can also be seen that L. monocytogenes was isolated from all the samples except for the Inegol kofte made out of beef, and hamburgers made out of chicken meat and preserved by freezing. The results indicate that there are no significant differences in terms of $L$. monocytogenes isolation based on the meat type and preservation method. This result implies that preservation by cooling or freezing the meatballs is not very effective. The factors effective in L. monocytogenes contaminations are mostly environmental contaminations and crosscontamination through the equipment used during the production stage $(16,17,21,28,29)$. On the other hand, the fact that antibacterial properties of some spices like clove, thyme, onion, and garlic used in the production of meatballs having a negative effect on the $L$. monocytogenes count and vitality should also be kept in mind $(5,13)$.

The L. monocytogenes isolation prevalence of some samples was lower in our study compared to the literature $(23,28,29)$ while others were higher (11). Such variations may be based on the differences between the production and preservation methods employed by the production companies, the inhibition effect of some of the additives and spices used during the production of the meatballs or the competing microflora, or due to the differences in analysis methods used $(5,13)$.

The equipment used, and the preferred hygiene protocols like HACCP and GM used by the production plants, also play an important part in the contamination of meat and meat products by Listeria spp. In the establishments that produce ready-made meatballs, the Listeria spp. that have spread to the equipment used can keep contaminating the products continuously, which may be a contributor to the high isolation rates revealed by the studies $(12,28,29)$.

The species that was isolated the most in this study was L. monoctogenes, followed by L. innocua. Sharif and Tunail (23) isolated L. monocytogenes the most from more than 200 meat product samples they tested consisting of frozen cooked, half-cooked, thermally pre-processed, and raw products, and also found it was followed by $L$. innocua. Sireli et al. (28), on the other hand, found $L$. innocua was the predominant species for minced meat, meatball and burger samples, which was followed by $L$. monocytogenes.

In our study, the $\mathrm{pH}$ value for the meatball samples was found to vary between 5.16 and 7.75 , with mean of $6.62 \pm 0.56$. The $\mathrm{pH}$ range detected in our study is wider compared to the study of Soyutemiz (25) (which detected a pH range of 5.85-7.32 in ready-made meatballs), which may be due to the difference in regions from which the samples were collected from. Some researchers report that a high initial $\mathrm{pH}$ value in Inegol kofte's stored in $+4{ }^{\circ} \mathrm{C}$ is connected to the bicarbonate used in the production, and the drop at the $7^{\text {th }}$ day is due to the acids produced by the micro-flora (27). The $\mathrm{pH}$ values in our study were found to be of alkali range for Tekirdag kofte, Izmir kofte, odun kofte, 1zgara kofte, and some of the Inegol kofte samples, while it was found to be below pH 7.0 for the others (Table 2).

In the statistical analysis, some significant differences $(\mathrm{P}<0.05)$ were found in terms of $\mathrm{pH}$ value among the frozen ready-made beef meatball groups (Table 2). Among the groups of cooled ready-made beef meatballs a significant difference $(\mathrm{P}<0.05)$ was found only between Inegol kofte group and hamburger kofte/kasap kofte groups (Table 2). In groups contains more than one different types of meatballs, the differences between the $\mathrm{pH}$ values of some types of meatballs were found to be significant $(\mathrm{P}<0.05)$ only in Inegol kofte group (Table 2$)$. No significant difference was found between meatball types in hamburger kofte, kasap kofte and cizbiz kofte groups in terms of $\mathrm{pH}$ values (Table 2). These variations may be related to the difference of raw materials, additives, and micro-flora of the samples, to the preservation method employed, or to variances in the storage period length. Soyutemiz (25) has found that hamburgers had a lower $\mathrm{pH}$ value on average compared to other meatball types. While the $\mathrm{pH}$ values found in our study for the hamburgers were lower compared to the study of Soyutemiz (25) and similar to the study of Yörük (29), our study also has revealed that hamburger meatballs had a comparatively lower $\mathrm{pH}$ nonetheless.

The water activities of the samples were found to vary between $0.975 \pm 0.015$ and $0.992 \pm 0.003$, with mean of $0.985 \pm 0.007$. In the statistical analysis, some significant differences $(\mathrm{P}<0.05)$ were found in terms of $\mathrm{a}_{\mathrm{w}}$ value among the frozen ready-made beef meatball groups (Table $3)$. Also, among the groups of cooled ready-made beef meatballs a significant difference $(\mathrm{P}<0.05)$ was found only between $\mathrm{a}_{\mathrm{w}}$ values of hamburger kofte group and kasap kofte group (Table 3). In addition, in the statistical analysis of the $a_{w}$ values of the meatballs types in the groups, while there was no significant difference between the types of meatballs in the kasap kofte group and the c1zbiz kofte group, there were some significant differences 
between the types of meatballs in the Inegol kofte group and hamburger kofte group (Table 4). When the water activity of the products are considered, some statistically significant differences $(\mathrm{P}<0.05)$ between both the groups and sub-groups can be observed (Table 3 and Table 4). It can be thought that this situation is due to the raw material, production and preservation differences for all product groups.

In the correlation analysis performed to determine whether there is a relationship between the $\mathrm{pH}$ values and $a_{w}$ values of meatball groups, only in hamburger kofte samples were found to have a negative correlation $(\mathrm{P}<0.05)$ between $\mathrm{pH}$ and water activity values. This finding may be due to fact that half of the hamburger kofte samples were stored by cooling, where some psychrophilic microorganisms may have multiplied in the storage temperature, causing acidity $(5,26)$.

The Microbiological Criteria Code of the Turkish Food Codex mandates zero L. monocytogenes in $25 \mathrm{~g}$ of the sample for ready-made meatballs (3). Evaluated in this perspective, it is evident that $11.04 \%$ of the samples inspected in our study are in violation of the legal regulations. This situation suggests that these products may pose a serious public health hazard, in situation such as cooking with inadequate heat treatment and crosscontamination with uncooked foods.

As a result of this study, it has been revealed that meatballs preserved by cooling or freezing in the sale points are contaminated with Listeria species, especially with L. monocytogenes, and this contamination level is capable for forming a significant risk for the public health. This risk may further increase with inadequate cooking time or methods before consumption (10). The results clearly indicate that trusting the products preserved by cooling or freezing to be perfect in terms of food safety is a faulty perspective. To prevent these kinds of pathogenic risks, the ready-made meatballs have to be produced by paying the utmost attention to hygiene rules and must be delivered to the final consumer without breaking the cold chain.

\section{Acknowledgement}

This study was partially supported by the Van YYU Directorate of Scientific Research Projects under project number 2008-VF-B059.

\section{References}

1. Akcan T, Estévez M, Serdaroglu M (2017): Antioxidant protection of cooked meatballs during frozen storage by whey protein edible films with phytochemicals from Laurus nobilis L. and Salvia officinalis. Food Sci Technol-LEB, 77: 323-331.

2. Anonymous (2015). IBM SPSS Statistics for Windows, Version 23.0. IBM Corp., Armonk, NY, USA.
3. Anonymous (2011). Turkish Food Codex, Regulation on Microbiological Criteria. R. Gazete: 29.12.2011/28157, Ankara.

4. Anonymous (1984). Difco Manual. Tenth. Edition. Detroid Michigan USA, 1984.

5. Arshad MS, Batool SA (2017): Natural antimicrobials, their sources and food safety. 87-102. In: DN Karunaratne (Ed), Food Additives, InTech, DOI: 10.5772/intechopen.70197.

6. Aznar R, Alarcón B (2003): PCR detection of Listeria monocytogenes: a study of multiple factors affecting sensitivity. J Appl Microbiol, 95: 958-966.

7. Border P, Howard J, Plastow G, et al (1990): Detection of Listeria species and Listeria monocytogenes using polymerase chain reaction. Lett Appl Microbiol, 11: 158162.

8. Can OP, Sahin S, Ersan M, et al (2013): Sivas kofte and examination of microbiological quality. Biotech Anim Husbandry, 29(1): 133-143.

9. Cook LV (1998): Isolation and identification of Listeria monocytogenes from red meat, poultry, egg and enviromental samples. 1-20. In: BP Dey, CP Lattuada (Eds.) Microbiology Laboratory Guidebook, Chapter $8,3^{\text {rd }}$ Ed., United States Department of Agriculture Food Safety and Inspection Service Office of Public Health and Science Microbiology Division, Athens, Georgia USA.

10. Daelman J, Jacxsens L, Devlieghere F, et al (2013): Microbial safety and quality of various types of cooked chilled foods. Food Control, 30(2): 510-517.

11. Dogruer Y, Telli N, Telli AE, et al (2015): Presence and antibiotic susceptibility of Listeria monocytogenes in retail meat and meat products. International Journal of Biological Research, 3(2): 76-81.

12. Henriques AR, Gama LT, Fraqueza MJ (2017): Tracking Listeria monocytogenes contamination and virulenceassociated characteristics in the ready-to-eat meat-based food products industry according to the hygiene level. Int $\mathrm{J}$ Food Microbiol, 242: 101-106.

13. Jolly D, Menon V (2015): Antibacterial effect of garlic and ginger extracts on Escherichia coli and Listeria monocytogenes. International Journal of Applied and Pure Science and Agriculture, 1(2):111-118.

14. Lachica V (1990): Simplified Henry technique for initial recognition of Listeria colonies. Applied Environmental Microbiology, 56(4): 1164-1165.

15. McClain D, Lee WH (1988): Development of USDA-FSIS method for isolation of Listeria monocytogenes from raw meat and poultry. J Assoc Off Anal Chem, 71(3):660-664.

16. Miladi H, Elabed H, Ben Slama R, et al (2017): Molecular analysis of the role of osmolyte transporters opuCA and betL in Listeria monocytogenes after cold and freezing stress. Arch Microbiol, 199(2): 259-265.

17. Oxaran V, Lee SHI, Chaul LT, et al (2017): Listeria monocytogenes incidence changes and diversity in some Brazilian dairy industries and retail products. Food Microbiol, 68: 16-23.

18. Ozbey G, Icyeroglu A, Muz A (2013): Prevalence of Listeria species in raw hamburger meatballs and chicken burgers in eastern Turkey. Afr J Microbiol Res, 7(31): 4055-4058. 
19. Ozturk HM, Ozturk HK, Kocar G (2017): Microbial analysis of meatballs cooled with vacuum and conventional cooling. J Food Sci Technol, 54(9): 2825-2832.

20. Rocourt J (1988): The Recognition and identification of Listeria species by classical methods. Turkish Journal Infection, 2(4): 471-485.

21. Saldivar JC, Davis ML, Johnson MG, et al (2018): Listeria monocytogenes adaptation and growth at low temperatures: mechanisms and implications for foodborne disease. 227-248. In: SC Ricke, GG Atungulu, CE Rainwater, SH Park (Eds.). Food and Feed Safety Systems and Analysis, Academic Press, San Diego, USA.

22. Seeliger HPR, Jones D (1986): Genus Listeria. 1235-1245. In: PHA Sneath, NS Mair, ME Sharpe, JG Holth, Bergey's Manual of Systematic Bacteriology. Vol 2, Williams \& Wilkins, Baltimore, USA.

23. Sharif A, Tunail N (1995): Detection of Listeria monocytogenes in foods of animal origin. Turk J Vet Anim Sci, 19: 329-334.

24. Soyutemiz GE (1999): Hygienic quality of different readymade meatballs consumed in Bursa. G1da Derg, 24(3): 163169.
25. Soyutemiz GE (2000a): Chemical composition and $p H$ values of five different groups ready-made meat balls consumed in Bursa. Gida Derg, 25(1):49-53.

26. Soyutemiz GE (2000b): Changes in bacterial flora and Listeria monocytogenes counts in vacuum packed Inegol meatballs refrigerated at different degrees. Gida Derg, 25(2): 79-86.

27. Soyutemiz GE (2001): Survival of Listeria monocytogenes in Inegol meatballs refrigerated at $4{ }^{\circ} \mathrm{C}$. Ist Univ Vet Fak Derg, 27(1): 115-126.

28. Sireli UT, Erol İ, Şahin S, et al (2002): Prevalence and contamination levels of Listeria spp. in poultry minced, poultry meatballs and poultry burgers. Turk J Vet Anim Sci, 26: 1271-1276.

29. Yörük NG (2012): Investigation of frankfurter sausage, Mortadella type cooked sausage, fermented dry sausage and hamburger patty for foodborne pathogens produced by meat plants having ISO Food Safety Regulation. PhD Thesis, 116 page, Selçuk University, Institute of Health Sciences, Konya, Turkey. 